\title{
Severe Struvite Urolithiasis in Saanen Kids
}

Saanen Olaklarnda Şiddetli Strüvit Ürolitiyazisi

\section{Mehmet Çağr1 KARAKURUM ${ }^{1 *}$ (D) Şima ŞAHİNDURAN ${ }^{1}$ (D) Metin Koray ALBAY1(D)}

${ }^{1}$ Burdur Mehmet Akif Ersoy University, Faculty of Veterinary Medicine, Department of Internal Medicine, Burdur, Turkey

\begin{abstract}
The owner of a goat flock admitted to our clinic with three intact male Saanen kids (3 months of age) with the complaints of stranguria, anuria, and colic. One kid was totally anuric, the other two was dribbling little urine. Anuric kid was dead shortly after submission. One of the other two kids was dead 4 hours after submission to our clinic and a necropsy was performed on both kids. Several urolithiasis extracted from the cortex, pelvis of kidneys, ureters and bladders. After necropsy, urolith samples were subjected for analysis and reported as struvite. Then, the farm was visited and urine was collected from all kids $(n=23)$ and 15 of them was positive for struvite urolithiasis according sediment examination. Vitamin C $(20 \mathrm{mg} / \mathrm{kg})$ as powder was prescribed for four weeks and correction of the ration and gradually increasing the salt content of ration to $\% 4$ was adviced. Four weeks later no struvite crystals were seen microscopically. Correction of ration and use of Vitamin $C$ resulted in dissoluation of struvite crystals and prevented the further occurrence of urolithisis. Vitamin $\mathrm{C}$ can be used as a safe urine acidifier in kids.
\end{abstract}

Anahtar Kelimeler: Struvite urolithiasis, Kids, Ration, Vitamin C.

Öz: Bir keçi sürüsünün sahibi kliniğimize üç adet kastre edilmemiş erkek Saanen oğlağında (3 aylık) stranguria, anüri ve kolik şikayetleri ile başvurdu. Bir oğlak tamamen anürikti, diğer ikisinde ise çok az miktarda idrar damlatma vardı. Anürik oğlak getirildikten kısa bir süre sonra öldü. Diğer iki oğlak ise kliniğimize başvurduktan 4 saat sonra öldü ve üçüne de nekropsi yapıldı. Korteks, böbrek pelvisi, üreterler ve mesanelerden birçok taş toplanarak nekropsi sonrası analize tabi tutuldu ve struvit olarak rapor edildi. Daha sonra çiftlik ziyaret edildi ve tüm oğlaklardan $(\mathrm{n}=23)$ idrar topland1 ve bunlardan 15'i sediment muayenesine göre struvit ürolitiazis için pozitifti. C vitamini $(20 \mathrm{mg} / \mathrm{kg})$ toz olarak dört hafta boyunca verildi ve rasyonun düzeltilmesi ile rasyonun tuz içeriğinin kademeli olarak \% 4'e yükseltilmesi tavsiye edildi. Dört hafta sonra mikroskobik olarak hiçbir struvit kristali görülmedi. Rasyonun düzenlenmesi ve $C$ vitamini kullanımı, struvit kristallerinin erimesine neden oldu ve daha fazla ürolit oluşumunu engelledi. C vitamini, oğlaklarda güvenli bir idrar asitleştiricisi olarak kullanılabilir.

Keywords: Strüvit ürolitiyazisi, Oğlak, Rasyon, C Vitamini.

*Corresponding author : Mehmet Çă̆rı KARAKUM e-mail : mckarakurum@mehmetakif.edu.tr Geliş tarihi / Received : 13.11.2019 Kabul tarihi / Accepted: 03.12.2019

\section{Introduction}

Urolithiasis is a metabolic disease characterised by formation of calculi within the urinary tract and may cause urethral blockage (Belknap and Pugh, 2002). Urolith formation is considered to have a multifactorial aetiology, however diet has been supposed as the major factor. Ruminants fed rations high in phosphorus, such as cereal grains, commonly develop struvite (magnesium ammonium phosphate) calculi. High concentration of magnesium in feedlot ration also causes a high prevalence of magnesium ammonium phosphate calculi in lambs (Makhdoomi and Gazi, 2013; Radostits et al., 2005). It is the most common cause of urinary tract disease in goats and sporadic occurrence can affect animal health and welfare. In goats, obstructive urolithiasis commonly seen in youngcastrated males due to phosphate salts especially Magnesium ammonium phosphate and calcium 
phosphate (Belknap and Pugh, 2002; Smith and Sherman, 2009).

Although uroliths can be found anywhere within the urinary tract, urethroliths are responsible for most clinical problems. Young castrated animals are at the greatest risk because of decreased lumen size of urethra related to a reduction in the circulating androgenic hormones. Due to a shorter and wider urethra in which calculi can pass easily, female goats and kids are not predisposed (Belknap and Pugh, 2002; Radostits et al., 2005; Smith and Sherman, 2009).

Treatment of obstructive urolithiasis is generally surgical to remove uroliths. Management and dietary factors should be considered to establish a preventive approach for urolithiasis such as maintaining calcium to phosphorus ratio of 2:1 in the ration and adding salt to stimulate the water consumption and to increase urine output. Also struvite crystals can be prevented by urine acidification. Generally, ammonium chloride and Vitamin $\mathrm{C}$ are advised for urine acidification (Van Metre and Smith 1991, Belknap and Pugh, 2002; Makhdoomi and Gazi, 2013; Mavangira et al., 2010)

The purpose of the present article is to describe clinical course and treatment with Vitamin $\mathrm{C}$ in Saanen kids with struvite urolithiasis.

\section{Materials and Methods}

The owner of a goat flock admitted to our clinic with three intact male Saanen kids (3 months of age) with the complaints of stranguria, anuria, and colic. One kid was totally anuric, the other two was dribbling little urine. In the anamnesis it was stated that 10 male kids were dead with the same symptoms in 3 days. On physical examination, kids were dehydrated, reluctant to walk and depressed. There was a tight bladder on abdominal palpation. Painful attempts to urinate and vocalizing were observed. One kid had gritty mineral deposits on preputium. Blood samples (for haemogram and serum biochemistry) and urine via cystocentesis obtained for laboratory analysis. Results were shown in Table 1,2. Anuric kid was dead shortly after submission and the one of other two was dead 4 hours after submitted to our clinic and a necropsy was performed on both. An intravenous catheter was placed in survived kid and was sedated with diazepam $(0.25 \mathrm{mg} / \mathrm{kg}$, IV). Meloxicam $(0.6 \mathrm{mg} / \mathrm{kg} \mathrm{IV})$ was given for analgesia and hyoscine butylscopolamine ( $2 \mathrm{~mL}$ IV) for its spasmolytic effect. After sedation urethral process was removed and uretra was massaged. Shortly after this manipulation gritty mineral depositions was milked out and urine flow started.

Table 1. Haemogram and Serum Biochemistry Findings

\begin{tabular}{lcc}
\hline & Kid 1 & Kid 2 (Survived) \\
\hline Leukocyte $(\mathrm{x} \mathrm{109/ \textrm {L } )}$ & 24.000 & 18.000 \\
Erythtocyte $(\mathrm{x} \mathrm{1012/L)}$ & 6.400 & 6.800 \\
Haemotocrit $(\%)$ & $\% 48$ & $\% 50$ \\
Haemoglobin $(\mathrm{g} / \mathrm{dL})$ & $\% 14$ & $\% 13$ \\
Urea $(\mathrm{mg} / \mathrm{dL})$ & 148 & 151 \\
Creatinine $(\mathrm{mg} / \mathrm{dL})$ & 8.4 & 6.9 \\
\hline
\end{tabular}


Table 2. Urinalaysis Findings

\begin{tabular}{lcc}
\hline & Kid 1 & Kid 2 (Survived) \\
\hline Density & 1.015 & 1.020 \\
Color & Reddish & Reddish \\
Appereance & Cloudy & cloudy \\
$\mathrm{pH}$ & 8.0 & 8.0 \\
Protein & +++ & +++ \\
Keton & + & - \\
Glucose & - & - \\
Blood & +++ & +++ \\
Microscopy & Numerous erythrocyte, leukocyte & Numerous erythrocyte, leukocyte and \\
& and struvite crystals & struvite crystals \\
\hline
\end{tabular}

\section{Results}

At the necropsy bladders was intact and distended with reddish urine. Kidneys were enlarged. Several urolithiasis extracted from the cortex, pelvis of kidneys and bladders (Figure 1,2). Also a urolith seen in ureter in anuric kid, which was lead to hidronefrosis (Figure 3). After necropsy, urolith samples were subjected for analysis and reported as struvite.

Then, the farm was visited and urine was collected from all kids $(n=23)$ and 15 of them was positive for struvite urolithiasis according to the urinalysis and sediment examination. It was seen that the ration given to the kids was random (Low fiber, high grain) and mineralized artesian water was used for water source. Vitamin C (20 mg/kg) as powder was prescribed for four weeks and correction of the ration and gradually increasing the salt content of ration to $\% 4$ was adviced. Urine $\mathrm{pH}$ was checked 1 week apart to ensure the urine $\mathrm{pH}$ was between 6-6.5. Four weeks later after initiation of Vitamin C therapy, no struvite crystals were seen microscopically. Dietary management and use of Vitamin $C$ resulted in dissoluation of struvite crystals and prevented the occurrence of urolithisis. No other kid was dead in this period.

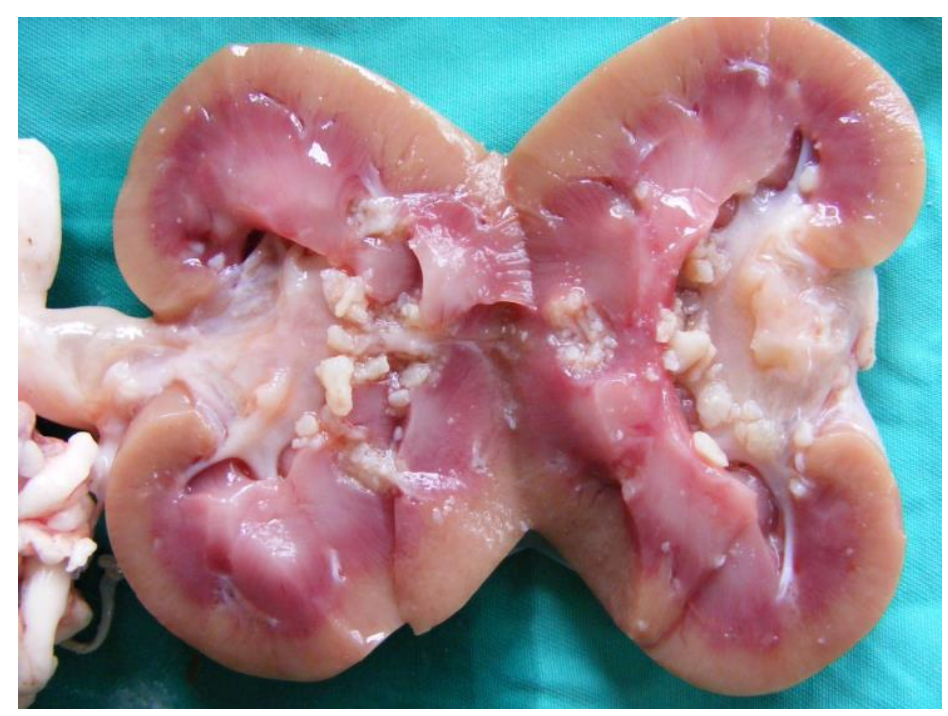

Figure.1 Uroliths in cortex and pelvis of kidneys 


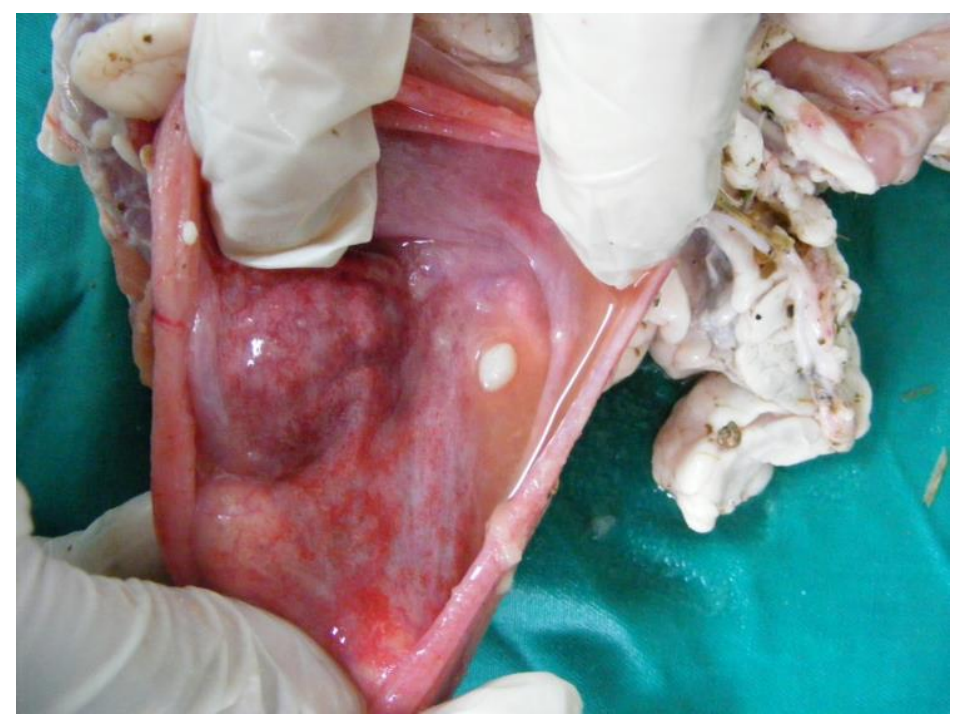

Figure 2. Urolith in bladder

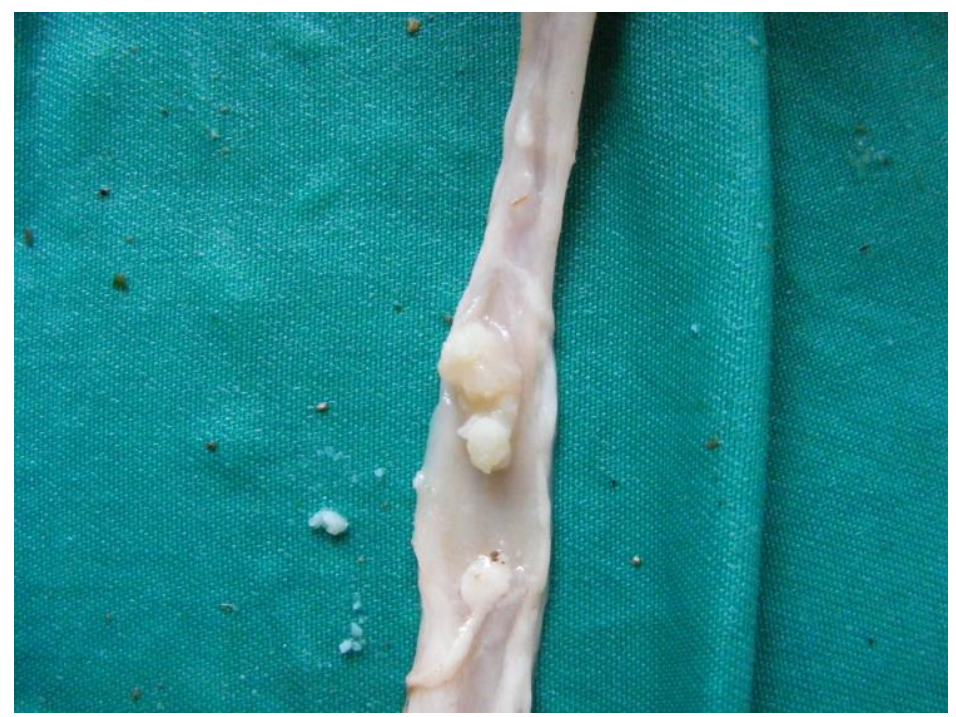

Figure 3. An urolith seen in ureter in anuric kid, which was lead to hidronefrosis

\section{Discussion}

Urolithiasis is a common frustrating disorder in both sexes in goats, however urinary blockage is usually seen among males of any age but particularly castrated male goats (Matthews, 2016; Riedi et al., 2018, Videla and Van Amstel 2016). Castration causes interruption of penile development, so the urethra remains narrow
(Belknap and Pugh, 2002; Smith and Sherman, 2009). Although early castration has reported as one of the main causes of urolithiasis in sheep and goats none of the kids in this study was castrated.

Uroliths are formed by precipitation or crystallisation of mineral salts on an organic matrix. Their formation is, therefore, dependent on a number of factors, especially dietary and 
environmental. Uroliths in goats and sheep are most commonly reported as phosphatic complexes and calcium salts. Phosphatic complexes include magnesium ammonium phosphate (struvite) and calcium phosphate; occur in alkaline urine; associated with consumption of cereals and pelleted rations. Factors which increase urinary phosphorus excretion increase the risk of the formation of insoluble phosphates and urinary calculi. In ruminants, urinary excretion of phosphorus is normally very low (Matthews, 2016; Radostits et al., 2005). Excess phosphorus is secreted into the digestive system via saliva and excreted in the faeces. But at a certain level the salivary phosphorus recycling system becames saturated and urinary phosphorus excretion occurs. Low levels of dietary calcium also oppose phosphorus absorption in the intestine. If the dietary calcium:phosphate ratio is low $(<1.5: 1)$ phosphorus absorption and therefore urinary phosphorus load is increased. Low fibre/high grain diets also cause a decrease in amounts of saliva thus decreasing the amount of phosphorus excreted in the faeces. Any reduction in voluntary water consumption will lead to concentrated urine and increased likelihood of calculi formation (Matthews, 2016; Radostits et al., 2005; Videla and Van Amstel 2016). A genetic predisposition to calculi formation has been reported in Saanen males (Matthews, 2016). Random ration is thought to be the biggest source of the problem in this farm. The fact that the farm owner does not receive any nutritional advice support before the problem and that the problem is not repeated when the ration is arranged in order to prevent the re-occurrence of the problem shows that our hypothesis is correct.

Management and dietary factors should be considered to establish a preventive approach for urolithiasis. Providing calcium to phosphorus ratio of 2:1 in the ration and increasing the salt levels to stimulate the water consumption and to increase urine output and urine dilution is essential. Also struvite crystals can be prevented by urine acidification. Generally, ammonium chloride is advised for urine acidification (Van Metre and
Smith 1991, Makhdoomi and Gazi, 2013; Mavangira et al., 2010), however prolonged use of ammonium chloride may cause osteopenia and also not palatable for animals (Radostits et al., 2005; Smith and Sherman, 2009). Vitamin C was reported to obtain satisfactory results in acidifying sheep urine even in small doses $(3-4 \mathrm{mg} / \mathrm{kg}$ ) and has no major side effects (Belknap and Pugh, 2002). In the present study the authors chose the Vitamin $\mathrm{C}$ as urine acidifier and checked the acidifier effect 5 day apart. Vitamin $\mathrm{C}$ provided a good urine $\mathrm{pH}$ of 6-6.5 for four weeks. Also no side effects seen that can be attributed to Vitamin C.

In conclusion, it was seen that struvite urolithiasis may be seen in an early age such as 3 month in non-castrated kids. Dietary management and use of Vitamin $\mathrm{C}$ resulted in dissoluation of struvite crystals and prevented the occurrence of urolithisis. Vitamin $\mathrm{C}$ can be used as a safe urine acidifier in kids.

\section{References}

Belknap, E.B., Pugh, D. G., 2002. Diseases of the urinary system. In: Pugh D.G. (Ed). Sheep \& goat medicine. Philadelphia: Saunders, pp.267271.

Makhdoomi, D.M., Gazi, M.A., 2013 Obstructive urolithiasis in ruminants - A review Veterinary World 6(4), 233-238.

Matthews J., 2016. Diseseases of the Goat. 4th Edition. Wiley-Blackwell.

Mavangira, V., Cornish, J.M., Angelos, J.A., 2010. Effect of ammonium chloride supplementation on urine $\mathrm{pH}$ and urinary fractional excretion of electrolytes in goats. Journal of the American Veterinary Medical Association 237,1299-1304.

Radostitis, O.M., Blood, D.C., Gray, G.C., Hinchcliff, K.W., 2005. Veterinary Medicine a text book of the disease of cattle, sheep, pig, goat and horse. Bailliere Tindall, London.

Riedi, A.K., Knubben-Schweizer, G., Meylan, M., 2018. Clinical findings and diagnostic procedures in 270 small ruminants with 
obstructive urolithiasis. Journal of Veterinary Internal Medicine 32,1274-1282.

Smith, M.C., Sherman, D.M., 2009. Goat medicine. 2nd edn. Wiley-Blackwell.

Van Metre, D.C., Smith, B.P., 1991. Clinical management of urolithiasis in small ruminants, Proceedings of the Ninth Annual Forum, American College of Veterinary Internal Medicine, New Orleans, pp 555-557.

Videla R, van Amstel S., 2016. Urolithiasis. Veterinary Clinics of North America: Food Animal Practice 32(3), 687-700. 